Vol 5 No 1 (2022) 115-128 P-ISSN 2620-295 E-ISSN 2747-0490

DOI: 1047467/elmal.v5i1.650

\title{
Strategi Manajemen Sumber Daya Manusia Islami Dalam Meningkatkan Produktivitas Kinerja Karyawan di Koperasi Syariah 212 Sentul
}

\author{
Caesya Noor Avissa, H. Ikhwan Hamdani, H. Suyud Arif \\ Universitas Ibnu Khaldun Bogor \\ cae.na99@gmail.com, onehamdani@gmail.com, suyudarif@fai.uika-bogor.ac.id
}

\begin{abstract}
This study aims to explain the strategy of human resource management in increasing the productivity of the performance of employees in the Sharia Cooperative 212 Sentul and how appropriate human resource management is with Islamic law. This study uses a qualitative approach with data collection techniques in the form of interviews and documentation. The resource persons in this study were the head of the human resources division and two employees in Cooperative 212. The results of the study stated that the Human Resource Management Strategy implemented in Cooperative 212 was by providing training, every year there was an employee performance appraisal and increasing ability in communicate. Cooperatives have implemented Human Resource Management in accordance with Islamic law because Cooperative 212 has done things that do not violate Islamic rules such as being honest at work, having a sense of responsibility, maintaining trust, and self-evaluation. Thus, employees are able to produce a positive impact, but the implementation is still less than perfect because the implementation of the strategy used has not been carried out regularly and well structured. However, the leadership is expected to improve the Human Resource management strategy so that the Sharia Cooperative 212 can develop and not deviate from Islamic rules.
\end{abstract}

Keywords: Islamic Human Resource Management Strategy, Employee Performance Productivity, Sharia Cooperative 212.

\section{ABSTRAK}

Penelitian ini bertujuan untuk menjelaskan strategi manajemen sumber daya manusia dalam meningkatkan produktivitas kinerja karyawan yang berada di Koperasi Syariah 212 Sentul dan bagaimana kesesuainnya manajemen sumber daya manusia denga syariat Islam. Penelitian ini menggunakan pendekatan kualitatif dengan teknik pengumpulan data berupa wawancara dan dokumentasi. Narasumber dalam penelitian ini adalah kepala divisi bagian sumber daya manusia dan dua orang karyawan yang ada di Koperasi 212. Hasil penelitian menyatakan Strategi Manajemen Sumber Daya Manusia yang diterapkan di Koperasi 212 yaitu dengan cara memberikan pelatihan, setiap tahun ada penilaian kinerja karyawan dan meningkatkan kemampuan dalam berkomunikasi. Koperasi telah menerapkan Manajemen Sumber Daya Manusia sesuai dengan syariat Islam karena Koperasi 212 telah melakukan hal-hal yang tidak melanggar aturan islam seperti jujur dalam bekerja, mempunya rasa tanggung jawab, menjaga kepercayaan, dan evaluasi diri . Dengan demikian, karyawan mampu menghasilkan dampak yang positif, namun dalam penerapannya masih kurang dari kesempurnaan karena penerapan strategi yang digunakan belum dilakukan secara teratur dan terstruktur dengan baik. Namun pimpinan diharapkan dapat meningkatkan strategi manajemen Sumber Daya Manusia tersebut agar Koperasi Syariah 212 dapat berkembang dan tidak melenceng dari aturan islam.

Kata Kunci : Strategi Manajemen Sumber Daya Manusia Islami, Produktivitas Kinerja Karyawan, Koperasi Syariah 212.

\section{PENDAHULUAN}




\section{Vol 5 No 1 (2022) 115-128 P-ISSN 2620-295 E-ISSN 2747-0490 DOI: 1047467/elmal.v5i1.650}

Manajemen Sumber Daya Manusia adalah peran yang dilakukan dalam perusahaan yang mempromosikan penggunaan orang yang paling efisien untuk mencapai tujuan perusahaan dan individu. Tanpa penggunaan yang berhasil dan produktif dari karyawan perusahaan, sulit untuk mencapai Tujuan Organisasi SDM, karena karyawan memiliki bakat, kemampuan dan inovasi serta upaya latihan dan kepemimpinan yang berkontribusi pada tingkat keberhasilan organisasi. Oleh karena itu, SDM perlu diselaraskan dan diterapkan dengan benar untuk menghasilkan kinerja yang diinginkan. Bagi perusahaan, dalam mengelola sumber daya manusia bukanlah hal yang mudah. Tujuan manajemen sumber daya manusia adalah untuk meningkatkan kontribusi karyawan terhadap organisasi dalam rangka pencapaian produktivitas organisasi yang bersangkutan. Pada dasarnya Sumber Daya Manusia sangat berkaitan dengan produktivitas kerja yaitu kemampuan karyawan dalam menghasilkan sesuatu dibandingkan dengan penggunaan Sumber Daya Manusia yang ada dalam sebuah organisasi tersebut, maka dari itu produktivitas Sumber Daya Manusia masih perlu ditingkatkan dengan cara melalui program pendidikan dan pelatihan. Program pendidikan dan pelatihan hendaknya disusun secara cermat dan didasarkan pada cara-cara serta berpedoman pada keterampilan yang dibutuhkan oleh perusahaan saat ini maupun masa yang akan datang. Pendidikan dan pelatihan bertujuan untuk meningkatkan kemampuan agar produktivitas kerja Sumber Daya Manusia dapat meningkat sesuai dengan keterampilan yang sudah diperolehnya..

\section{TINAJAUAN LITERATUR}

\section{Strategi Manajemen Sumber Daya Manusia}

Strategi Manajemen Sumber Daya Manusia adalah melakukan kebijakankebijakan Sumber Daya Manusia berdasarkan kemampuan karyawan dan perilaku yang diperlukan perusahaan untuk mencapai tujuan strategisnya. Istilah strategi pada masa sekarang dapat didefinisikan sebagai rencana-rencana jangka panjang atau tindakan-tindakan yang direncanakan dengan baik untuk mencapai tujuan, kesuksesan, atau perkembangan masa depan.

Strategi Manajemen Sumber Daya Manusia memandang fungsi SDM sebagai bagian integral dari semua fungsi perusahaan/organisasi seperti pemasaran, produksi, pembiayaan, hukum dan sebagainya. Departemen SDM harus mengerti bagian operasional, memahami kompleksitas desain organisasi dan harus bisa menentukan kemampuan tenaga kerjanya dimasa sekarang dan masa depan, termasuk menghadapi perubahan yang terjadi.

\section{Indikator Manajemen Sumber Daya Manusia}

\section{Rekrutmen}

Rekrutmen merupakan aktivitas yang dirancang untuk memperoleh pelamar kerja yang memenuhi persyaratan yang ditetapkan oleh perusahaan. Perusahaan akan mencari tenaga baru apabila terjadi kekurangan tenaga kerja yang diperlukan 
Vol 5 No 1 (2022) 115-128 P-ISSN 2620-295 E-ISSN 2747-0490 DOI: 1047467/elmal.v5i1.650

oleh perusahaan. Efektivitas sebuah perusahaan bergantung pada produktivitas para karyawannya.

\section{Seleksi}

Seleksi adalah proses memilih pelamar untuk dijadikan karyawan dan menempatkan mereka pada posisi yang dibutuhkan oleh perusahaan. Dalam menyeleksi karyawan baru, departemen sumber daya manusia biasanya menyaring pelamar melalui wawancara, tes, dan menyelidiki latar belakang pelamar. Selanjutnya, merekomendasikan pelamar yang memenuhi persyaratan pada manajer untuk diambil keputusan pengangkatan terakhir.

\section{Pengembangan}

Pengembangan merupakan serangkaian aktivitas yang dirancang untuk meningkatkan kemampuan, keterampilan, sikap, dan kinerja sumber daya manusia. Aktivitas ini mengajarkan keahlian baru, memperbaiki keahlian yang ada, dan memengaruhi sikap dan tanggung jawab para karyawan. Aktivitas pengembangan dirancang untuk mendidik karyawan sehingga mereka siap dipromosikan dan mampu memandang peran mereka dalam organisasi secara lebih luas.

\section{Penilaian Kinerja}

Penilaian Kinerja merupakan salah satu faktor kunci dalam mengembangkan suatu organisasi secara efektif. Dengan dilakukannya penilaian kinerja berarti suatu organisasi telah memanfaatkan secara baik sumber daya manusia di dalam organisasi. Informasi yang terpercaya tentang prestasi kerja sangat diperlukan untuk meningkatkan kinerja para karyawan karena akan mempermudah perumusan kebijakan lebih lanjut. Informasi yang akurat dari prestasi kerja secara individual akan sangat bermanfaat bagi kemajuan organisasi secara keseluruhan.

\section{Kompensasi}

Kompensasi dalam kamus besar bahasa Indonesia, secara terminologi berarti ganti rugi. Kompensasi di dalamnya menggunakan sistem pengkajian yang adil. Islam menetapkan upah bagi pegawainya sesuai dengan kondisi, tanggung jawab dan jenis pekerjaan.

Dalam suatu organisasi, pengaturan kompensasi merupakan faktor penting untuk dapat memelihara dan mempertahankan prestasi kerja para karyawan. Suatu kompensasi dapat berupa finansial ataupun non-finansial. Pada umumnya, istilah kompensasi dipakai dalam pengertian proses pengadministrasian gaji dan upah. Suatu kompensasi akan dapat meningkatkan maupun menurukan memotivasi kerja karyawan.

\section{Pemeliharaan Keselamatan Kerja}

Keselamatan kerja adalah kondisi yang aman dan kondusif dalam lingkungan kerja. Aspek keselamatan kerja mencakup perlindungan akan risiko terjadinya 
Vol 5 No 1 (2022) 115-128 P-ISSN 2620-295 E-ISSN 2747-0490 DOI: 1047467/elmal.v5i1.650

penderitaan, kerusakan, hingga kerugian di tempat kerja. Keselamatan kerja dapat diwujudkan dengan bekerja dan menggunakan alat kerja sesuai standar operasional prosedur (SOP) yang berlaku, serta menjaga tempat kerja agar memiliki potensi bahaya yang minim.

Setiap organisasi bisnis diharapkan memiliki program keselamatan kerja guna mengurangi kecelakaan kerja dan kondisi kerja yang tidak sehat. Setiap karyawan perlu secara terus-menerus diingatkan dan dijamin tentang pentingnya keselamatan kerja dan diarahkan agar menghindari kecelakaan kerja.

\section{Manajemen Sumber Daya Manusia dalam Islam}

\section{Shiddiq (Benar)}

Shiddiq merupakan salah satu sifat utama Rasulullah Muhammad SAW yang berarti benar, memiliki kejujuran, dan selalu melandasi ucapan. Oleh karena itu Allah swt. memerintahkan orang-orang yang beriman untuk senantiasa memiliki sifat Shiddiq dan menciptakan lingkungan yang Shiddiq.

Kejujuran ditampilkan dalam bentuk kesungguhan dan ketepatan. Tampilannya dapat berupa : ketepatan waktu, janji, pelayanan, pelaporan, mengakui kelemahan dan kekurangan, melakukan perbaikan secara terus-menerus, menjauhkan diri dari kebohongan dan menipu. Bisnis yang dipenuhi kebohongan dan manipulasi seperti ini tidak akan mendapat rahmat dan barokah dari Allah swt. Karena tidak mencerminkan perilaku bisnis syariah seperti apa yang telah dicontohkan oleh Rasulullah SAW.

\section{Amanah (dapat Dipercaya)}

Amanah artinya dapat dipercaya dan bertanggung jawab. Amanah bisa juga bermakna keinginan untuk memenuhi sesuatu sesuai dengan ketentuan. Dan amanah juga merupakan salah satu moral keimanan. Seorang Muslim haruslah memiliki sifat amanah, karena Allah menyebutkan sifat orang-orang mukmin yang beruntung adalah manusia yang dapat memelihara amanat yang diberikan kepadanya.

Amanah juga berarti memiliki tanggung jawab dalam melaksanakan tugas dan kewajiban yang diberikan kepadanya. Amanah dapat ditampilkan dalam bentuk: keterbukaan, kejujuran, dan pelayanan yang optimal. Moralitas amanah akan melahirkan perilaku penuh tanggung jawab (responsible), berani mengambil resiko (caourageous risk taker), dan professional (profesionalisme).

\section{Fathanah (Cerdas)}

Fathanah adalah salah satu sifat rasukl yang artinya cerdas, cemerlang, dan tepat. Sifat fathanah dapat dipandang sebagai strategi hidup setiap Muslim. Seorang Muslim harus mengoptimalkan segala potensi yang telah diberikan oleh Allah SWT. Potensi yang paling berharga dan termahal hanya diberikan oleh Allah kepada manusia yaitu akal. Allah swt. 


\section{Vol 5 No 1 (2022) 115-128 P-ISSN 2620-295 E-ISSN 2747-0490 DOI: $1047467 /$ elmal.v5i1.650}

Kecerdasan yang dimaksudkan di sini adalah ketika mempergunakan akal yang telah diberikan Allah kepada hamba-Nya untuk memikirkan dan mempertimbangkan antara haq (kebenaran) dan kebathilan (kemungkaran), termasuk juga kecerdasan spiritual. Dengan adanya sifat fathanah ini maka akan menumbuhkan kreativitas dan kemampuan untuk melakukan berbagai macam inovasi yang bermanfaat.

\section{Tabligh (Menyampaikan)}

Tabligh merupan salah satu sifat yang dicontohkan Rasulullah SAW yang menjadi kunci keberhasilan dalam menjalankan tugas kerasulannya. Tabligh adalah menyampaikan pesan dari Allah SWT secara penuh dan tuntas tanpa ada yang disembunyikan.

Seorang karyawan harus mampu menyampaikan keunggulan-keunggulan produknya dengan jujur dan tidak berbohong tentang kekurangan produknya (tidak menipu). Seorang karyawan harus menjadi seorang komunikator yang baik yang bisa berbicara dengan benar dan bijaksana dan tepat sasaran kepada mitra kerjanya. Kalimat-kalimat yang keluar dari ucapannya berbobot dan tidak menyinggung

\section{Produktivitas Kerja}

\section{Definisi Produktivitas Kerja}

Definisi produktivitas menurut Nasution (2002:203) menjelaskan bahwa produktivitas merupakan konsep rasio, yaitu rasio output terhadap input menjadi lebih besar. Dengan demikian, nilai rasio output dibuat menjadi lebih besar melalui peningkatan salah satu output pada tingkat input yang konstan, mengurangi pengunaan input, atau kombinasi keduanya.

Produktivitas menurut mempunyai pengertian sebagai sikap mental yang berpandangan bahwa hari ini harus lebih baik dari hari kemarin dan hari esok harus lebih baik dari hari ini. Produktivitas memilki dua dimensi, dimensi pertama adalah efektivitas yang mengarah kepada pencapaian unjuk kerja yang maksimal yaitu pencapaian target yang berkaitan dengan kualitas, kuantitas, dan waktu, dan yang kedua yaitu efisiensi yang berkaitan dengan upaya membandingkan input dengan realisasi penggunaannya atau bagaimana pekerjaan tersebut dilaksanakan (Umar, 2004).

Dari pengertian diatas dapat diketahui bahwa penilaian produktivitas selain dapat dihitung antara perbandingan output dan input, juga dapat dinilai dengan melihat proses pelaksanaan kegiatan manajemen. Kemampuan manajemen untuk menggunakan sumber-sumber secara maksimal dan menciptakan sistem kerja yang optimal, akan menentukan tinggi rendahnya produktivitas kerja karyawan. Peranan manajemen sangat strategis untuk peningkatan produktivitas, yaitu dengan menggabungkan dan mendayagunakan semua sarana produksi, menerapkan fungsifungsi manajemen, menciptakan sistem kerja, menempatkan orang yang tepat pada 
Vol 5 No 1 (2022) 115-128 P-ISSN 2620-295 E-ISSN 2747-0490

DOI: 1047467/elmal.v5i1.650

pekerjaan yang sesuai serta menciptakan kondisi dan lingkungan kerja yang aman dan nyaman.

\section{Manfaat Produktivitas Kerja}

Manfaat produktivitas kerja karyawan adalah sebagai berikut :

a. Menimbulkan Kewajiban Organisasi

b. Menimbulkan Loyalitas Kerja Karyawan

c. Meningkatkan hasil yang dicapai dengan penggunaan sumber daya yang efektif dan efisien.

d. Meningkatkan prestasi kerja karyawan dan perusahaan

\section{Indikator Produktivitas Kinerja Karyawan}

Produktivitas merupakan hal yang sangat penting bagi para karyawan yang ada di perusahaan. Dengan adanya produktivitas kerja diharapkan pekerjaan akan terlaksana secara efesien dan efektif, sehingga ini sangat diperlukan dalam pencapaian tujuan yang sudah ditetapkan. Menurut Sutrisno (2009) untuk mengukur produktivitas kerja, diperlukan suatu indikator, sebagai berikut :

\section{Kemampuan}

Mempunyai kemampuan untuk menjalankan tugas, kemampuan seorang karyawan sangat bergantung pada keterampilan yang dimiliki serta profesionalisme mereka dalam bekerja.

\section{Hasil yang dicapai}

Hasil merupakan salah satu yang dapat dirasakan baik oleh yang mengerjakan maupun yang menikmati hasil pekerjaan tersebut. Upaya untuk memanfaatkan produktivitas kerja bagi masing-masing yang terlibat dalam suatu pekerjaan.

Sebagaimana yang disampaikan oleh divisi bagian Sumber Daya Manusia dalam wawancara :

\section{Semangat kerja}

Indikator ini dapat dilihat dari cara kerja dan hasil yang dicapai dalam satu hari kemudian dibandingkan dengan hari sebelumnya.

Sebagaimana yang disampaikan oleh divisi bagian Sumber Daya Manusia dalam wawancara :

\section{Pengembangan diri}

Pengembangan diri dapat dilakukan dengan melihat tantangan dan harapan dengan apa yang akan dihadapi. Semakin kuat tantangannya, pengembangan diri pasti dilakukan. Begitu juga harapan untuk menjadi lebih baik akan berpengaruh pada karyawan untuk meningkatkan kemampuan dalam bekerja.

\section{Mutu}




\section{Vol 5 No 1 (2022) 115-128 P-ISSN 2620-295 E-ISSN 2747-0490 DOI: $1047467 /$ elmal.v5i1.650}

Mutu merupakan hasil pekerjaan yang dapat menunjukan kualitas pegawai. Meningkatkan Mutu bertujuan untuk untuk memberikan hasil kerja yang terbaik dan akan sangat berguna bagi perusahaan dan diri sendiri.

\section{Efisiensi}

Efisiensi adalah perbandingan antara hasil yang dicapai dengan sumber keseluruhan sumber daya yang telah digunakan. Efisiensi berupa input dan output yang merupakan aspek produktivitas dan memberikan pengaruh cukup penting bagi karyawan.

\section{A. METODE PENELITIAN}

\section{Jenis Penelitian}

Metode yang digunakan dalam penelitian ini adalah metode penelitian kualitatif, Metode penelitian kualitatif adalah metode penelitian yang digunakan untuk mendalami dan memahami pemahaman berdasarkan metodologi yang bersifat menganalisa fenomena keadaan sosial masyarakat (Sugiyono 2017). Dalam melakukan penelitian kualitatif, peneliti memperoleh dan mengumpulkan data-data deskriptif yang berupa ucapan, kata-kata, maupun gambar yang selanjutnya akan dikelola menjadi sajian data deskriptif. Menurut Jane Richie Penelitian kualitatif adalah upaya untuk menyajikan dunia sosial, dan perspektifnya dalam dunia, dari segi konsep, perilaku, persepsi dan persoalan tentang manusia yang diteliti.

\section{Jenis dan Sumber Data}

\section{Data Primer}

Adalah data yang diperoleh dari hasil observasi dan wawancara langsung dengan responden melalui pengajuan wawancara tak terstruktur. Perolehan data primer dilakukan dengan metode penarikan sampel, yaitu dengan menggunakan metode-metode stratified random sampling dan purposive sampling.

\section{Data Sekunder}

Adalah data yang diperoleh dari hasil studi perpustakaan, baik berupa bahanbahan bacaan maupun data angka. Jenis data ini sering juga disebut data eksternal. Data sekunder bersumber dari dokumen-dokumen dan data dari Koperasi itu sendiri.

\section{Teknik \& Pengumpulan Data}

Menurut Bogdan dan Biklen dalam (Ahmadi, 2014:230) analisis data merupakan suatu proses penyelidikan dan pengaturan secara sistematis transkrip wawancara, catatan lapangan, dan material-material lain yang dikumpulkan untuk meningkatkan pemahaman tentang data. Pengumpulan data adalah prosedur yang sistematik dan standar untuk memperoleh data yang diperlukan, pengumpulan data dapat dilakukan dalam berbagai setting, berbagai sumber, dan berbagai cara (Mamik, 
Vol 5 No 1 (2022) 115-128 P-ISSN 2620-295 E-ISSN 2747-0490 DOI: 1047467/elmal.v5i1.650

2014:103). Data yang diperoleh dalam penelitian ini menggunakan teknik pengumpulan data sebagai berikut :

\section{a. Wawancara}

Teknik ini dilakukan dengan memperoleh data dan informasi langsung dari responden mengenai permasalahan yang dikaji melalui wawancara. Metode wawancara ini digunakan untuk mengetahui hubungan dengan sumber data, melalui tanya jawab untuk mendapatkan informasi yang diperlukan. Susunan kata-kata dalam setiap pertanyaan dapat diubah pada saat wawancara, disesuaikan dengan kebutuhan dan kondisi saat wawancara mengenai strategi manajemen sumber daya manusia dalam meningkatkan kinerja karyawan pada Koperasi 212 yang fokusnya adalah kepala pimpinan manajemen sumber daya manusia Koperasi 212.

\section{b. Dokumentasi}

Dokumentasi asal katanya dokumen, yang artinya bahan tertulis yang berhubungan dengan suatu peristiwa atau aktivitas tertentu. Dokumen yang digunakan dalam penelitian ini adalah informasi yang disimpan atau didokumentasikan seperti dokumen, soft file, data otentik dan arsip lainnya yang berhubungan dengan sumber daya manusia yang dapat digunakan sebagai pelengkap dari data yang diperoleh dalam kegiatan wawancara dan observasi. Di dalam melaksanakan metode dokumentasi, peneliti menyelidiki benda-benda tertulis seperti buku-buku, majalah, dokumen, peraturan-peraturan, notulen, catatan harian, dan sebagainya.

\section{HASIL DAN PEMBAHASAN}

\section{Strategi Manajemen Sumber Daya Manusia}

\section{a. Rekrutmen dan Seleksi}

Pemilihan karyawan merupakan aktivitas kunci untuk menentukan jalannya sebuah perusahaan. Maka, atasan harus selektif dalam memilih calon karyawannya, yaitu orang yang berkompeten, memiliki pengetahuan luas, rasa tanggung jawab, dan dapat dipercaya. Koperasi Syariah 212 merupakan Koperasi yang bernuansa Islami. Sehingga dalam proses rekrutmen, kriteria calon tenaga kerja diantaranya adalah berakhlak baik, open-minded, dan diwajibkan beragama Islam, terutama untuk karyawan perempuan diwajibkan menggunakan busana yang menutup aurat dan berhijab. Proses rekrutmen juga dilakukan secara adil dengan tidak membeda-bedakan antara calon karyawan satu dengan yang lain. Namun, masih ada kendala sehingga proses dan kebutuhannya juga berubah, contohnya Koperasi masih belum menempatkan karyawan belum sepenuhnya tepat di tempat yang tepat. Dan 
Vol 5 No 1 (2022) 115-128 P-ISSN 2620-295 E-ISSN 2747-0490 DOI: 1047467/elmal.v5i1.650

dari divisi masing-masing mereka butuh spesifikasi dalam kemampuan, perkembangan dalam karyawan tersebut. Dan semua divisi harus konsisten dan komitmen sehingga Manajemen Sumber Daya Manusia sesuai dengan kebutuhannya.

Perusahaan harus berusaha untuk memperoleh dan menempatkan karyawan yang berkualitas pada setiap jabatan dan pekerjaan agar pelaksanaan pekerjaan lebih efisien. Karyawan yang berkualitas akan menghasilkan hasil yang berkualitas dan cepat selesai tepat pada waktunya, sehingga perusahaan tidak mendapatkan kerugian karena pekerjaan yang tidak selesai tepat pada waktunya. Dalam hal ini, agama Islam juga mengarahkan kita kepada sikap kehati-hatian dalam menyeleksi untuk mencapai hasil yang terbaik. Proses seleksi yang dilaksanakan di Koperasi Syariah 212 yaitu hanya mengandalkan pada seleksi wawancara dan pengalaman kerja, tidak ada seleksi tertulis. Seleksi wawancara dilaksanakan untuk mengetahui latar belakang, kemampuan karyawan, dan perusahaan cenderung akan memilih pelamar yang berpengalaman. Dan proses seleksi juga dilakukan secara adil pada setiap pelamar.

\section{b. Pengembangan}

Islam memandang bahwa ilmu merupakan dasar penentuan martabat dan derajat seseorang dalam kehidupan. Allah memerintahkan kepada RasulNya untuk senantiasa meminta tambahan ilmu. Dengan bertambahnya ilmu, akan meningkatkan pengetahuan seorang muslim terhadap berbagai dimensi kehidupan, baik urusan dunia atau agama. Sehingga, ia akan mendekatkan diri dan lebih mengenal Allah, serta meningkatkan kemampuan dan kompetensinya dalam menjalankan tugas pekerjaan yang dibebankan kepadanya. Pelatihan merupakan bentuk ilmu untuk meningkatkan kinerja, dimana Islam mendorong umatnya untuk bersungguh-sungguh dan memuliakan pekerjaan. Islam mendorong untuk melakukan pelatihan terhadap para karyawan dengan tujuan mengembangkan kompetensi dan kemampuan teknis karyawan dalam tanggung jawab pekerjaannya. Dan pengembangan keterampilan inilah yang akan membawa karyawan untuk menjadi lebih baik. Dan Koperasi Syariah 212 melatih keterampilan tersebut dengan cara pelatihan dan pendidikan yang intensif dan pelatihan tersebut berdasarkan dari masing-masing divisi.

\section{c. Penilaian Kinerja}

Penilaian kinerja di Koperasi Syariah 212 sangat dibutuhkan untuk menilai produktivitas karyawan kepada perusahaan. Penilaian kinerja dilakukan secara non formal yaitu diawasi oleh tenaga kerja yang sudah lama bekerja di perusahaan dan sudah berkompeten. Penilaian kinerja dilakukan dengan melihat sikap tenaga kerja yaitu kejujuran dan tanggung jawab, rajin beribadah, kedisiplinan, keterampilan dan ketelitian dalam mengerjakan 
Vol 5 No 1 (2022) 115-128 P-ISSN 2620-295 E-ISSN 2747-0490 DOI: 1047467/elmal.v5i1.650

pekerjaannya. Proses penilaian kinerja yang dilakukan di Koperasi Syariah 212 tersebut sudah sesuai dengan aturan Islam, bahwa Islam mendorong umatnya untuk memberikan semangat dan motivasi bagi pegawai dalam menjalankan tugas mereka. Kinerja dan upaya mereka harus diakui, dan mereka harus dimuliakan jika memang bekerja dengan baik. Karyawan yang menunjukkan kinerja baik, akan diberi bonus dengan tujuan menghargai prestasi yang telah dicapai. Dengan adanya penilaian kinerja maka karyawan dapat menilai bagaimana kinerja mereka dalam periode tertentu, sehingga diharapkan adanya tindakan perbaikan yang diambil.

\section{d. Kompensasi}

Kompensasi merupakan aspek penting karena berpengaruh terhadap kinerja karyawan dan juga dapat mempertahankan karyawan untuk tetap bekerja diperusahaan tersebut, sehingga tidak terjadi turnover yang tinggi. Setiap orang yang bekerja wajib menerima upah atau balas jasa. Sistem pembayaran kompensasi yang diterapkan di Koperasi Syariah 212 menggunakan sistem payroll dari rekening bank masing-masing sehingga karyawan-karyawan tersebut bisa terima secara langsung. Namun sistem pemberian kompensasi tersebut masih banyak kekurangannya seperti ada permasalahan dalam penghitungan kompensasi, Koperasi Syariah 212 masih menggunakan cara Manual. Dan terkadang tidak memberikan upahnya secara tepat waktu, padahal dalam Islam sangat dianjurkan untuk memberikan upah secara tepat waktu, Ketentuan tersebut untuk menghilangkan keraguan pekerja atau kekhawatirannya bahwa upah mereka tidak akan dibayarkan, atau mengalami keterlambatan tanpa adanya alasan yang dibenarkan. Namun demikian, umat Islam diberikan kebebasan untuk menentukan waktu pembayaran upah sesuai dengan kesepakatan antara pekerja dan pemimpin perusahaan, atau sesuai dengan kondisi.

\section{e. Pemeliharaan Keselamatan Tenaga Kerja}

Syariat Islam menegaskan bahwa mencegah bahaya lebih diprioritaskan ketimbang mengupayakan kemaslahatan, apabila kemaslahatan seimbang dengan bahaya keterpautan keduanya tidak jelas. Untuk menjamin keselamatan kerja dalam berkarya di berbagai sektor industri, menjaga keselamatan jiwa manusia dan lingkungan kerja merupakan usaha melestariakan kehidupan. Sebagai perusahaan yang telah menyiapkan alat-alat perlindungan diri dari ancaman kecelakaan kerja, hendaknya diiringi pula dengan kesipan mental tenaga kerja sebelum melakukan pekerjaan untuk memelihara ketenangan, baik ketenangan pribadi (lahir dan batin) maupun ketenangan lingkungan kerja. Sebaliknya sikap tergesa-gesa dapat merusak pekerjaan dan membuatnya tidak bermutu sebagaimana yang diharapkan. Rasulullah SAW telah memperingatkan agar dalam setiap tindakan dalam beraktifitas selalu berhati-hati. Tidak diragukan 


\section{Vol 5 No 1 (2022) 115-128 P-ISSN 2620-295 E-ISSN 2747-0490 DOI: $1047467 /$ elmal.v5i1.650}

lagi bahwa kebisingan merupakan salah satu sebab terjadinya ketegangan dan keguncangan jiwa serta mempengaruhi produktifitas kerja.

Koperasi Syariah 212 sudah menggunakan peralatan keselamatan kerja sesuai dengan SOP yang sudah ditentukan contohnya menyediakan buku petunjuk, Peraturan pembagian tugas dan tanggung jawab, dan tempat kerja yang aman sesuai standar syarat-syarat lingkungan kerja, sarana dan prasarana yang lengkap di tempat kerja, dan kesadaran dalam menjaga keselamatan dan kesehatan kerja.

\section{b. Kesesuaian Strategi Manajemen Sumber Daya Manusia dengan Syariat Islam}

Manajemen Sumber Daya Manusia dalam Koperasi Syariah 212 sudah sesuai dengan syariat Islam karena Koperasi Syariah 212 telah melakukan hal-hal yang tidak melanggar syariat islam contohnya rajin ibadah seperti sholat berjamaah, tadarrus qur'an, dan tidak merokok, tidak minum minuman keras. Ada juga seperti karyawan menjaga kualitas dalam produknya, cara menyampaikan kemasan produk mereka secara spesifik, menerima keluhan dari konsumen secara terbuka, tidak menutupi kekurangan dalam produk, dan bertanggung jawab jika produk tersebut memiliki kecacatan.

\section{Amanah (dapat dipercaya)}

Amanah adalah menjaga kepercayaan yang diberikan orang lain kepada dirinya. Amanah adalah salah satu karakteristik orang yang beriman. Orang amanah adalah orang yang dapat menjaga kepentingan diri sendiri dan kepentingan orang lain. Ia dapat berlaku adil terhadap dirinya dan orang lain dan tidak tergoda mengambil keuntungan sepihak diatas kerugian orang lain. Tanpa adanya kepercayaan dari orang lain maka pada hakikatnya dia telah mati.

Di Koperasi 212, mereka cari solusi jika ada karyawan yang mempunyai masalah maupun itu pribadi atau pekerjaan, dan kunci yang paling penting dalam hubungan antar karyawan adalah saling memahami.

Dan karyawan juga melihat sisi kualitas dalam menjaga kepercayaan dari produk-produknya sehingga mereka sangat berhati-hati supaya produk tersebut tidak mengalami masalah, dan jika produk tersebut bermasalah harus ada perawatan dalam kualitas produk tersebut.

\section{Shiddiq}

Shiddiq berarti benar, meneguhkan, taat. Siddiq yang dimaksud disini adalah moralitas yang mendorong seseorang bersikap dalam perilaku yang teguh sesuai dengan kebenaran keyakinannya dan membenarkan keyakinan orang lain yang diyakini sebagai orang-orang yang benar.

Karyawan-karyawan di Koperasi 212 sangat memperhatikan kejujuran dalam kualitas produknya. Mereka akan memastikan kalau produk 
Vol 5 No 1 (2022) 115-128 P-ISSN 2620-295 E-ISSN 2747-0490 DOI: 1047467/elmal.v5i1.650

tersebut harus sesuai dalam penempatannya dan pengiriman ke tempat konsumen. Dan jika ada terjadi kesalahan dalam produksi, mereka tidak akan menutupi kekurangan mereka dan akan menjelaskan dimana kesalahan tersebut.

\section{Fathanah}

Fathanah berarti cerdas, memahami, dan cemerlang. Fathanah tidak hanya kecerdasan intelektual, tetapi juga meliputi kecerdasan emosional spiritual. Orang yang memiliki sifat fathanah akan memiliki insting yang tajam sehingga dapat membantu dalam mengambil keputusan yang tepat, cepat dan berani.

Koperasi tidak akan membahas tentang cacat dalam produkya. Tapi koperasi juga memperingatkan kepada konsumen untuk melakukan perawatan khusus kepada produknya misalkan syarat penyimpanan produk dengan baik, dengan cara tersebut produk dapat mencegah dari masalah yang akan datang.

\section{Tabligh}

Tabligh adalah menyampaikan pesan secara tuntas tanpa ada yang disembunyikan. Dalam kehidupan sehari-hari tabligh dapat dipahami dalam menjalani tugas yang menjadi tanggung jawab, sehingga prosesnya berjalan secara efektif dan hasilnya maksimal. Sedangkan dalam kehidupan berorganisasi tabligh tidak menyalahgunakan fasilitas dan tujuan organisasi untuk kepentingan pribadi atau kelompok.

Dalam mempromosikan produk, karyawan harus menjelaskan spesifikasi termasuk komposisi dan sumbernya secara detail sehingga konsumen bisa paham dengan produk tersebut. Karyawan juga menceritakan keunikan dari kemasan produk sehingga bisa memastikan apa kemasan tersebut tahan panas apa tidak, oleh karena itu karyawan harus memperingatkan konsumen untuk dapat perhatian khusus sehingga tidak terkena sinar matahari.

\section{KESIMPULAN}

1. Strategi Manajemen Sumber Daya Manusia yang diterapkan di Koperasi 212 dengan cara meningkatkan sosialisasi dan komunikasi. Bentuk-bentuk penerapannya seperti mengadakan rapat kerja secara rutin, membuat jadwal rutin dalam mengembangkan produknya, mencari solusi untuk karyawan jika mengalami masalah. Untuk proses Rekrutmen, calon karyawan wajib beragama Islam terutama bagi perempuan untuk menggunakan baju yang tidak ketat dan memakai jilbab. Proses Seleksi yang dilakukan di Koperasi Syariah 212 hanya mengambil karyawan yang berpikiran 


\section{Vol 5 No 1 (2022) 115-128 P-ISSN 2620-295 E-ISSN 2747-0490 DOI: $1047467 /$ elmal.v5i1.650}

terbuka, mempunyai komunikasi yang bagus, dan berkompeten. Proses pengembangan keterampilan karyawan dilakukan untuk karyawan yang baru, Koperasi Syariah 212 melatih keterampilan tersebut dengan cara pelatihan dan pendidikan yang intensif selama satu bulan dan pelatihan tersebut dari masingmasing divisi. Penilaian Kinerja karyawan yang dilakukan di Koperasi 212 dengan melihat sikap tenaga kerja yaitu kejujuran dan tanggung jawab, rajin beribadah, kedisiplinan, keterampilan dan ketelitian dalam mengerjakan pekerjaannya. Untuk sistem kompensasi Koperasi Syariah 212 menggunakan sistem payroll dari bank tertentu sehingga karyawan mendapatkan upah secara langsung dari rekening bank masing-masing. Kompensasi yang diberikan sesuai dengan kinerja dan apa yang diberikan karyawan kepada koperasi. Untuk pemeliharan keselamatan kerja, Koperasi Syariah 212 sudah menggunakan peralatan keselamatan kerja sesuai dengan SOP yang sudah ditentukan contohnya menyediakan buku petunjuk, Menyediakan peraturan pembagian tugas, dan Menyediakan tempat kerja sesuai standar lingkungan kerja, dan Memiliki kesadaran dalam menjaga keselamatan dan kesehatan kerja.

2. Manajemen Sumber Daya Manusia dalam Koperasi Syariah 212 sudah sesuai dengan syariat Islam karena Koperasi Syariah 212 telah melakukan hal-hal yang tidak melanggar syariat islam contohnya melakukan ibadah seperti sholat berjamaah, tadarrus qur'an secara rutin, dan tidak merokok, tidak minum minuman keras. Ada juga seperti karyawan menjaga kualitas dalam produknya, cara menyampaikan kemasan produk mereka secara spesifik, menerima keluhan dari konsumen secara terbuka, tidak menutupi kekurangan dalam produk, dan bertanggung jawab jika produk tersebut memiliki kecacatan. Dan langkah-langkahnya yaitu penerapan peraturan dalam koperasi harus dibenahi dan tidak melenceng dari syariah. Kedua yaitu muhasabah antar karyawan.

3. Pelatihan di Koperasi Syariah 212 untuk saat ini adalah meningkatkan soft-skill para karyawan, seperti kedisiplinan, dan totalitas dalam bekerja. Pelatihan tersebut sangat berpengaruh pada keterampilan karyawan. Dan pada pelatihan ini memiliki kelebihan dan kekurangan. Kelebihannya adalah karyawan menjadi lebih disiplin pada diri sendiri dan sadar akan tujuan utamanya. Sedangkan kekurangannya adalah masih ada karyawan yang belum melakukan pelatihan tersebut secara rutin.

\section{DAFTAR PUSTAKA}

Abdul Goffar (2020). MANAJEMEN SUMBER DAYA MANUSIA DALAM PERSPEKTIF ISLAM. Islamic Akademika : Jurnal Pendidikan \& Keislaman Vol. 7 No.1 tahun 2020, Issue No.1.

Desilia Purnama Dewi, SE., MM \& Harjoyo, SE., MM (2019). Manajemen Sumber Daya Manusia. UNPAM PRESS.

Dr. Hotner Tampubolon, S.E., MM. (2016). STRATEGI MANAJEMEN SUMBERDAYA MANUSIA DAN PERANNYA DALAM PENGEMBANGAN KEUNGGULAN BERSAING. Papas Sinar Sinanti Jakarta, 2016 
Vol 5 No 1 (2022) 115-128 P-ISSN 2620-295 E-ISSN 2747-0490 DOI: 1047467/elmal.v5i1.650

Dr. J. R. Raco, ME., M.Sc. (2010). METODE PENELITIAN KUALITATIF JENIS, KARAKTERISTIK, DAN KEUNGGULANNYA. Penerbit PT. Gramedia Widiasarana Indonesia, Jakarta Drs. H. Malayu S.P Hasibuan (2005). Manajemen Sumber Daya Manusia. Bumi Aksara, Jakarta 2005.

Irwan Misbach (2017). PERILAKU BISNIS ISLAM. Jurnal Al Idarah Volume 5, Juni 2017.

Khotibul Umam, M.Si. (2017). MANAJEMEN SUMBERDAYA MANUSIA (Sebuah Sudut Pandang dalam Tinjauan Islam). At-Thariq Jurnal Ilmiah Studi Keislaman dan Sosial, Volume 14, no 1, September 2017

M. Ma'ruf Abdillah (2012), Manajemen berbasis Syariah, (Slemen Yogyakarta: Aswaja Pressindo, 2012)

Tanjung, Hendri \& Devi, Abrista (2018), Metodologi Penelitian Ekonomi Islam 